\title{
From ISET to INDRE III. Sanitary and Tropical Diseases Institute: crisis and renewal, 1965-1989
}

\author{
Jorge Alejandro Ramírez-Hernández, ${ }^{1}$ María del Carmen Guzmán-Bracho, ${ }^{2 *}$ Martha Eugenia Rodríguez-Pérez, ${ }^{3}$ \\ Carlos Viesca-Treviño ${ }^{3}$ and José Alberto Díaz-Quiñonez ${ }^{1}$ \\ 'Universidad Nacional Autónoma de México, Faculty of Medicine, Division of Postgraduate Studies; ${ }^{2}$ Instituto de Diagnóstico y Referencia \\ Epidemiológicos "Manuel Martínez Báez"; '3niversidad Nacional Autónoma de México, Faculty of Medicine, Department of History and Philosophy \\ of Medicine. Mexico City, Mexico
}

\begin{abstract}
This paper analyzes the situation and the changes made in the Institute of Sanitary and Tropical Diseases between 1965 and 1989 to become the National Institute of Epidemiological Diagnosis and Reference. Three major stages are identified during this period: crisis, transition and renewal. The factors that led to the crisis, the decisions made to overcome it and to harmonize the work of laboratories with epidemiological and public health criteria are discussed. The recognition obtained by researchers of the Institute despite the crisis is described, as well as the way the institution managed to continue with projects despite the changing global situation. The transition included the arrival of a new generation of professionals with modern computer-based and conceptual tools and the remarkably well met challenge of participating in national surveys with rigorous criteria. All this moved the institution to define its profile towards diagnosis and reference.
\end{abstract}

KEY WORDS: Epidemiology. Institute of Sanitary and Tropical Diseases. National Institute of Epidemiological Diagnosis and Reference. History of medicine. History of public health.

\section{Desde el ISET al InDRE. III. Instituto de Salubridad y Enfermedades Tropicales: crisis y renovación, 1965-1989}

\section{Resumen}

El artículo analiza la situación y los cambios efectuados en el Instituto de Salubridad y Enfermedades Tropicales entre 1965 y 1989 para transformarse en el Instituto Nacional de Diagnóstico y Referencia Epidemiológicos. Se identifican tres grandes etapas en el periodo: crisis, transición y renovación. Se señalan los elementos que llevaron a la crisis, las decisiones que se tomaron para salir de ella y armonizar el trabajo de los laboratorios con criterios epidemiológicos y de salud pública. Se citan las distinciones obtenidas por investigadores del Instituto a pesar de la crisis y se describe cómo la institución logró seguir con proyectos a pesar de la cambiante situación mundial. La transición incluyó la llegada de una nueva generación de profesionales con modernas herramientas informáticas y conceptuales y el desafío de participar en encuestas nacionales con criterios rigurosos. Todo ello movió a la institución a definir su perfil hacia el diagnóstico y la referencia.

PALABRAS CLAVE: Epidemiología. Instituto de Salubridad y Enfermedades Tropicales. Instituto Nacional de Diagnóstico y Referencia Epidemiológicos. Historia de la medicina. Historia de la salud pública.

\footnotetext{
Correspondence:

Date of reception: 04-06-2019

*María del Carmen Guzman-Bracho

Date of acceptance: 30-07-2019

E-mail: cguzmanbracho@ @otmail.com

DOI: 10.24875/GMM.M20000371

Gac Med Mex. 2019;155:597-602

Contents available at PubMed license (http://creativecommons.org/licenses/by-nc-nd/4.0/).
} 


\section{Introduction}

This article gives continuity to the review of the life of the Sanitary and Tropical Diseases Institute (ISET - Instituto de Salubridad y Enfermedades Tropicales) between 1965 and 1989, ${ }^{1,2}$ when the crisis of the institutional model occurred and decisions were made to redirect it.

In those years, the epidemiological profile showed important changes for public health in the country, which were challenging for public policies. In the mortality tables, the predominance of infectious diseases was modified and non-communicable diseases and accidents became the main causes of death (Tables 1 and 2); however, diarrhea and pneumonia remained the main causes of morbidity. Life expectancy increased from 58.9 to 70.46 years from 1965 to 1989 at the national level, with the increase being higher in women than in men (13 years more for women and 10 more for men) (Figure 1). ${ }^{3-5}$

\section{ISET period of crisis}

The crisis of the institution can be traced between 1965 and 1977, which were years of reduced dynamism and innovation. An example of the crisis is illustrated by Clara Gorodezky's testimony. In 1965 she had an interview with the director with the purpose to join the ISET. In response, he recommended her to the Immunological Research laboratory, explaining her that at ISET "there were only routine activities and scarce research" (Clara Gorodezky, personal communication).

In addition, the researchers who were the founders of the Institute did retire or die in this period. Luis Mazzotti, Eustaquio Roch, Miguel E. Bustamante and Carlos Campillo Sainz left the ISET to engage in other professional activities; Manuel Martínez Báez got retired from institutional life in 1969, 6,7 although he retained an office there (Juan Manuel Campos, personal communication). Eliseo Ramírez Ulloa (1940), José Zozaya (1957), Mario Salazar Mallén (1976), Gerardo Varela (1977) and Antonio González Ochoa (1984) passed away. This generation did not pass on its legacy to a younger one for renewing the Institute. By 1960, the researchers salary, originally decent, ${ }^{1}$ was already insufficient. Young people with vocation and desire to investigate moved toward other institutions. ${ }^{8}$

Other important changes were recorded, such as the transformation of Revista del Instituto de Salubridad y Enfermedades Tropicales (ISET Journal). By
Table 1. Fifteen main causes of death from 1970 to $1975^{3}$

\begin{tabular}{|c|c|c|}
\hline No. & 1970 & 1975 \\
\hline 1 & Influenza and pneumonia & Influenza and pneumonia \\
\hline 2 & $\begin{array}{l}\text { Enteritis and other diarrheal } \\
\text { diseases }\end{array}$ & $\begin{array}{l}\text { Enteritis and other diarrheal } \\
\text { diseases }\end{array}$ \\
\hline 3 & Accidents or violent deaths & Accidents or violent deaths \\
\hline 4 & Heart diseases & Heart diseases \\
\hline 5 & $\begin{array}{l}\text { Causes of perinatal morbidity } \\
\text { and mortality }\end{array}$ & $\begin{array}{l}\text { Causes of perinatal morbidity } \\
\text { and mortality }\end{array}$ \\
\hline 6 & Malignant tumors & Malignant tumors \\
\hline 7 & Bronchitis & Cerebrovascular diseases \\
\hline 8 & Cerebrovascular diseases & Hepatic cirrhosis \\
\hline 9 & Measles & Diabetes mellitus \\
\hline 10 & Hepatic cirrhosis & Bronchitis \\
\hline 11 & Tuberculosis & Tuberculosis \\
\hline 12 & Vitamin deficiency & Vitamin deficiency \\
\hline 13 & Diabetes mellitus & Acute respiratory infections \\
\hline 14 & Anemias & Anemias \\
\hline 15 & Congenital anomalies & Congenital anomalies \\
\hline
\end{tabular}

1966, when it turned 27 years, it was given a new name: Revista de Investigación en Salud Pública (Journal of Public Health Research), which was maintained until 1977, when it became part of Revista de Salud Pública de México (Journal of Public Health of Mexico). ${ }^{9}$ This fact allowed to attract other branches of the Ministry of Public Health and Assistance for publishing. The denomination would be close to the name that the Ministry would adopt (Ministry of Health, 1982 ) and to that of the future Institute (National Institute of Public Health, 1987). The concept of public health allowed ISET to link to a worldwide movement that was broader than that of tropical medicine and was consistent with the postgraduate degrees in public health from five of its nine founding doctors.,10

The institutional crisis also faced other forms: early in the 1970 decade, the National Diagnostic and Reference Center was created within the ISET, under the direction of David Bessudo Madjar, with the purpose to coordinate laboratories that worked isolated from each other, in order to standardize their technical and information procedures in accordance with the epidemiological area. ${ }^{11,12}$ This way, a more adequate participation of ISET in epidemic outbreaks was allowed, such as the chloramphenicol-resistant salmonella-associated typhoid fever outbreak in 1972.13-15 


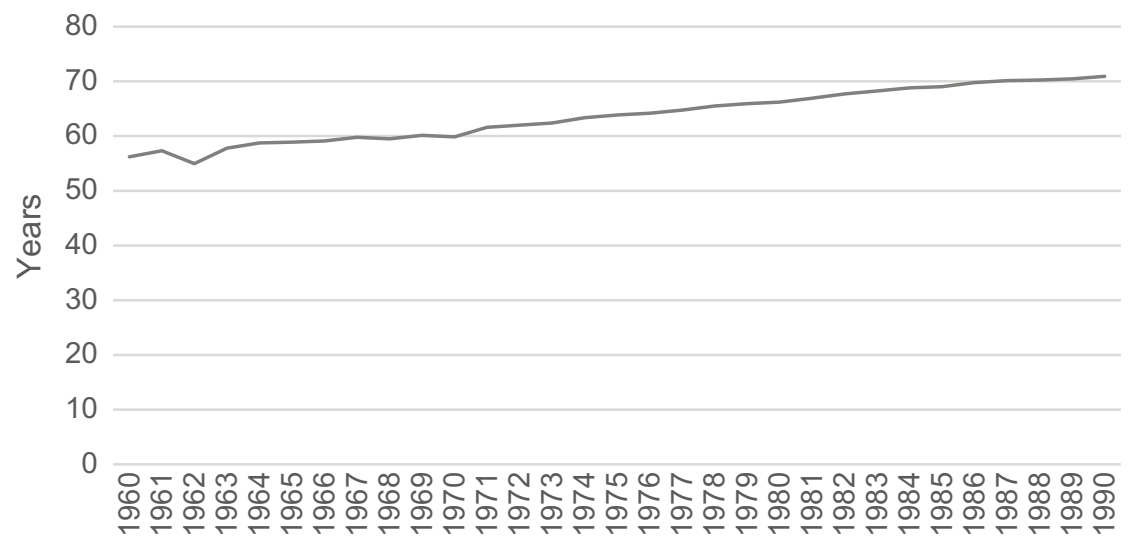

Figure 1. Life expectancy at birth in Mexico 1960-1990. Data available at Consejo Nacional de Población. Indicadores demográficos de México de 1950 a 2050.

\section{Table 2. Main causes of death from 1979 to 1989 in Mexico}

\section{No. Cause}

\section{Common causes of death in the period}

1 Acute myocardial infarction

2 Bronchopneumonia without undernutrition being mentioned

3 Other firearms and those not specified

$4 \quad$ Liver cirrhosis without alcoholism being mentioned

5 Colitis, enteritis and infectious gastroenteritis

6 Pneumonia, unspecified causative organism

7 Heart arrest

8 Colitis, enteritis and gastroenteritis of assumed infectious origin

9 Heart failure, not otherwise specified

10 Senility without psychosis being mentioned

11 Diabetes mellitus without complication being mentioned

12 Alcoholic liver cirrhosis

13 Other accidental causes, unspecified accidents

14 Pulmonary tuberculosis, not otherwise specified

\section{Causes of death incorporated at the end of the period}

1 Acute but ill-defined cerebrovascular disease

2 Other forms of protein-caloric undernutrition, not otherwise specified

3 Respiratory distress syndrome

4 Pedestrian

Source: Cubos dinámicos Instituto Nacional de Estadística y Geografía (INEGI)-Secretaría de Salud.

In the second half of the 70's, the profile of laboratory professionals gradually went on changing with the incorporation of young chemists. By 1977, the number
Table 3. Directors of the Sanitary and Tropical Diseases Institute, 1965-19896

\begin{tabular}{l|c|}
\hline Director & Period \\
\hline Gerardo Ignacio Varela Mariscal & $1959-1977$ \\
\hline Antonio González Ochoa* & $1975-1977$ \\
\hline Diego Fernández de Castro & $1977-1979$ \\
\hline Pablo Mendoza Hernández & $1980-1981$ \\
\hline Eduardo Zorrilla Hernández & $1981-1984$ \\
\hline David Bessudo Madjar* & $1984-1985$ \\
\hline Adolfo Pérez Miravete & $1985-1990$ \\
\hline *Temporary directors.
\end{tabular}

of doctors and chemists was already similar at ISET (58\% versus $42 \%$, respectively), ${ }^{16}$ a profile that included that of two executives: David Bessudo Madjar and Adolfo Pérez Miravete (Luis Ángel Sapian, personal communication) (Table 3). ${ }^{6}$

In conclusion, during the crisis, a programmed and also eventful attempt was made to revitalize selected laboratories. For example, production of antisera was started in order to typify enterobacteriaceae, and under the direction of Enriqueta Pizarro Suarez, the Respiratory Viruses Laboratory started operating, in support of influenza epidemiological surveillance. ${ }^{17,18}$

However, the above was not enough to redirect ISET's activities, which was still in a very difficult situation. We know about the dramatic testimony narrated by Miguel E. Bustamante to Antonio González Ochoa, when he defended the ISET against the threat to cancel its activities and asked the Secretary of Health and Assistance: "Do you want to go down in history as the secretary who shut down the ISET?..." And the 
cancellation of the Institute's activities was avoided (Alejandro Escobar, personal communication).

In this difficult period, several distinctions were conferred to ISET members, resulting from the inertia of its best moments. In 1972, Antonio González Ochoa was awarded the Science and Arts National Prize, and in 1977, the "Eduardo Liceaga" gold medal. ${ }^{19}$ In 1975, Gerardo Varela was awarded at the first edition of the National Prize of Chemistry and Pharmaceutical Sciences. In this period, some recipients of the "Gerardo Varela Award" had been ISET researchers: Jorge Olarte, 1976; Luis Vargas, 1978; and Jorge Fernández de Castro, $1988,{ }^{20}$ initial promoter of ISET's renovation as general director of epidemiology.

\section{International public health movement}

In the second half of the decade of 1970, new proposals of the World Health Organization emerged: Health for All by the Year 2000 (1977) and the International Conference on Primary Health Care in Alma-Ata (1978). Announcing the last cases of smallpox caused by natural infection in the world was added to this picture.

With an increase in international resources due to the rise of oil prices, in 1974, a program of interest for the ISET was organized: Tropical Diseases Research. The Immunology Research Laboratory received support to develop projects in onchocerciasis, a line of institutional work initiated since the decade of $1940^{16,21}$ (Alejandro Escobar, personal communication).

In 1981, the optimistic global outlook turned gloomy with the sharp drop of international oil prices. By 1982, Mexico implemented a structural adjustment, budgets were reduced and health sector strategies became selective. ${ }^{22}$ ISET maintained its renovating momentum and focused on vaccination programs; it contributed to the study of the immune protective response and of events temporarily associated with vaccination. ${ }^{23}$

\section{ISET transition to INDRE}

\section{The ISET National Center for Diagnosis and Reference}

At the beginning of the period in question, the diagnosis of viral diseases received an important boost to establish the etiology and mechanisms of disease transmission, and preventive and curative actions were updated. ${ }^{24,25}$
In this regard, the National Center for Diagnosis and Reference was integrated by laboratories for viral and bacterial diseases of public health importance, in addition to the Epidemiology Unit (David Bessudo Madjar, personal communication). The samples came from the medical units (health centers and hospitals) that participated in epidemiological surveillance special programs. The development of special epidemiological studies was added to diagnosis. ${ }^{26}$ In the Ministry of Health and Assistance restructuring in 1977, this center was considered a fundamental part of the ISET; changing the name of the institute to Center for Research on Transmissible Diseases was even, unsuccessfully, proposed. ${ }^{27}$

On December 5, 1977, a protocol document was signed, which transferred the ISET and the Immunological Research Laboratory administration to the General Directorate of Epidemiology and Public Health Research; ${ }^{28}$ in 1978 , the laboratory became dependent on ISET (although it was moved to the National Institute of Epidemiological Diagnosis and Reference [INDRE - Instituto Nacional de Diagnóstico y Referencia Epidemiológicos facilities until 1992). ${ }^{6}$ Its activities were enriched with the incorporation of laboratories with experience such as the Center of Venereal Diseases Diagnosis and Reference in April 1978. ${ }^{29}$

Another measure to integrate ISET to the General Directorate of Epidemiology was to locate the Sub-directorate of Epidemiological Research within the Institute, as well as a group of epidemiologists who had recently graduated from the School of Public Health of Mexico and who opened new lines of research. At the same time, the Public Health Infectology Laboratory Specialization Course was initiated, with a broad vision of laboratory networks in health and epidemiological management of disease and technological innovation for diagnosis (Jorge Ramírez Hernández and Carmen Guzmán Bracho, personal communication).

In 1984, the ISET began to assess the dynamics of soil-transmitted helminthiasis transmission, ${ }^{30}$ which was the basis of the National Deworming Program in the decade of 1990. In 1985, ISET became the first laboratory in the country with tests to confirm cases of human immunodeficiency virus infection (Roberto Vázquez Campuzano, personal communication).

The Institute received resources and equipment; after the September 1985 earthquake, the remodeling of the property was accelerated. The Serum Bank was created, which centralized the handling of nearly 70,000 samples obtained during the National 
Seroepidemiological Survey, for the initial study of nine diseases, inside and outside the Institute, defined according to their importance in public health as well as by the feasibility for them to be prevented or controlled: bacterial infections (whooping cough, brucellosis), viral infections (measles, rubella and polio), parasitic infections (cysticercosis, Chagas, toxoplasmosis) and metabolic conditions (total serum cholesterol). ${ }^{31}$ This survey was highly important to give ISET a new boost, with a young, professional, highly qualified team, which gave certainty to diagnosis in the health system. Technological development was promoted, for example, to typify Vibrio cholerae 01, Salmonella and Brucella. Serology had an important advance in the National Seroepidemiological Survey, by standardizing methodologies of its own, receiving specialized training at international reference centers and by incorporating professionals with training in specific areas.

\section{Evolution of a crucial aspect: epidemiological surveillance at ISET}

It is important to make a description of the element that was central to ISET's new orientation to be transformed into the Institute of Epidemiological Diagnostic and Reference: integration of the laboratory with epidemiological surveillance.

Since 1956, the World Health Organization promoted expert meetings in order to define the organization and operation of public health laboratories at each country. ${ }^{32}$ The ISET fully met the criteria issued in 1970 to be designated as central laboratory. Thus, the first stage of the creation of a network of laboratories with technical dependence on ISET's National Center of Diagnosis and Reference was proposed in 1974. ${ }^{12,33,34}$ The first laboratories, in Toluca and Guadalajara, started operating in the first half of the decade of $1970 .{ }^{35,36}$

As a consequence of the health services decentralization project, the creation of state public health laboratories was promoted, to the detriment of the regional laboratory project. Between the second half of the decade of 1970 and 1989, 11 more laboratories started operating: Yucatán, Guanajuato, Quintana Roo, Guerrero, Colima, Puebla, Tabasco, Chihuahua, Nuevo León, Zacatecas and Aguascalientes. This way, the pyramidal design of laboratories was integrated throughout the country. Thus, since late in the decade of 1980 , the counterpart to the 1940 National
Plan of Hospitals started being developed with a public health perspective.

\section{Change from ISET to INDRE}

With all the above events, the need to reorganize the Institute became evident. The property underwent a thorough refurbishment since 1985, and the authorities inside and outside the ISET discussed the idea of turning it into the National Institute of Epidemiological Diagnosis and Reference (INDRE - Instituto Nacional de Diagnóstico y Referencia Epidemiológicos). Finally after 50 years of existence, the change of denomination was carried out in 1989. ISET became INDRE, with a work program of great impact on national epidemiological surveillance and the huge challenge of recovering and strengthening its credibility.

\section{Discussion}

The purpose of this article has been to offer a vision of ISET's institutional evolution. For this study period, the personal testimony of at least one participant from each area of the Institute was obtained, which complemented the documentary review in 13 historical and newspaper archives.

These years (1965 to 1989) had their own characteristics for analysis. Revista ISET became Revista de Investigación en Salud Pública, and by 1977, it became part of Revista de Salud Pública de México. The journal change of name transcended ISET, ${ }^{10}$ and was to affect the Ministry of Health and the health sector in Mexico as a whole. The concepts of sanitary and tropical disease became less employed and were replaced by the health or public health concepts. We have described the forces that influenced to drive the ISET into crisis and the decisions that were made to solve it. An important point was renewing it with teams of young professionals and redefining its vocation towards epidemiological diagnosis and reference, concepts that had already been used at ISET since the decade of 1970, with the idea of establishing regional or state public health laboratories. This action gave balance to the epidemiology-laboratory binomial, to later become the Institute's central activity.

In 1985, closing the ISET clinic was decided when the new functions of the Institute were already being defined. Currently, the missing clinical component must be developed in collaborative protocols with national institutes of health. 
The boost to the training of young human resources specialized in epidemiology and public health laboratory, as well as the use of new computer technologies were crucial to guide the disease prevention and control programs. This allowed trust on the institution to be gained, where the National Seroepidemiological Survey was fundamental.

In 1989, the Sanitary and Tropical Diseases Institute was transformed into the National Institute of Epidemiological Diagnosis and Reference, which meant going from being an institute that was bound to a building to fully becoming the head of the complex network of laboratories for the diagnosis of infectious diseases that are subject to epidemiological surveillance in Mexico.

\section{Acknowledgements}

To the authorities and personnel of the Ministry of Health Historical Archive and to the interviewed colleagues: David Bessudo Madjar ( $\dagger$ ), Juan Manuel Campos Cervantes, Alejandro Escobar Gutiérrez, Clara Gorodezky Lauferman, Roberto Vázquez Campuzano and Luis Ángel Sapian López.

\section{References}

1. Ramírez-Hernández JA, Guzmán-Bracho C, Díaz-Quiñonez JA. 2019 Desde el ISET al InDRE. I. Instituto de Salubridad y Enfermedades Tropicales: génesis y primeros años, 1934-1940. Gac Med Mex. 2019;155(3):322-327. DOI: 10.24875/GMM.19005157.

2. Ramírez-Hernández JA, Guzmán-Bracho C, Viesca-Treviño C, Díaz-Quiñonez JA. Desde el ISET al InDRE. II. Instituto de Salubridad y Enfermedades Tropicales: Madurez y consolidación, 1940-1964. Gac Med Mex. 2019;155:391-398

3. Almada-Bay I. La mortalidad en México. México: Instituto Mexicano del Seguro Social; 1982.

4. Defunciones cifras oficiales definitivas. Cubos de defunciones 19792017. México: Instituto Nacional de Estadística y Geografía/Secretaría de Salud; 2019.

5. Consejo Nacional de Población. Indicadores demográficos de la República Mexicana, en el año. México: Consejo Nacional de Población; 2019

6. Valdespino-Gómez JL, García-García ML, Del Río-Zolezzi A, Escobar A Mora JL. El Instituto Nacional de Diagnóstico y Referencia Epidemiológicos "Dr. Manuel Martínez Báez" en 1994. En: Una institución académica y dieciséis investigadores distinguidos. Quincuagésimo quinto aniversario del INDRE. México: Secretaría de Salud; 1994.

7. Mazzotti L. Nota necrológica. Salud Publica Mex. 1971;13:983-984.

8. Archivo Histórico. Fondo Secretaría de Salubridad y Asistencia c44e1. México: Secretaría de Salud; 2019.
9. Marcial LD. Las publicaciones oficiales de la Secretaría de Salubridad y Asistencia. Salud Publica Mex. 1983:25:489-497.

10. Bustamante ME, Viesca-Treviño C, Villaseñor F, Vargas-Flores A, Castañón R, Martínez-Barbosa X. La salud pública en México 1959-1982. México: Secretaría de Salubridad y Asistencia; 1982.

11. Archivo Histórico de la Secretaría de Salud. Fondo Instituto de Salubridad y Enfermedades Tropicales c9e6. México: Secretaría de Salud;

12. Archivo Histórico. Fondo Instituto de Salubridad y Enfermedades Tropicales c23e1. México: Secretaría de Salud; 2019.

13. Fernández-De Castro J, Fernández-De Castro, H. Endemias y epidemias de México en el siglo XX. México: Siglo XXI Editores; 2015.

14. Pérez-Miravete A. A program for epidemiologic investigation of infections caused by Shigella dysenteriae type 1 in Mexico. Bol Oficina Sanit Panam. 1973;6:44-50.

15. González-Cortés A, Bessudo D, Fragoso R, Hinojosa M, Becerril P, Sánchez Leyva R, et al. Water-borne transmission of chloramphenicol-resistant Salmonella typhi in Mexico. Bull Pan Am Health Organ. 1974;302:605-607.

16. Archivo Histórico de la Secretaría de Salud. Fondo Secretaría de Salubridad y Asistencia c19e1. México: Secretaría de Salud; 2019.

17. Archivo Histórico de la Secretaría de Salud. Fondo Instituto de Salubridad y Enfermedades Tropicales c1e13. México: Secretaría de Salud; 2019

18. Archivo Histórico de la Secretaría de Salud. Fondo Instituto de Salubridad y Enfermedades Tropicales c23e4. México: Secretaría de Salud; 2019

19. Bonifaz-Trujillo A. Micología. En: Méndez-Oteo F. Historia gráfica de la medicina mexicana del siglo XX. México: Méndez Editores; 2019.

20. Premios que otorga el Consejo de Salubridad General. México: Consejo de Salubridad General; 2019.

21. Archivo Histórico de la Secretaría de Salud. Fondo Secretaría de Salubridad y Asistencia c2e4. México: Secretaría de Salud; 2019.

22. Walsh JA, Warren KS. Selective primary health care. New Engl J Med. 1979;30:1967-1974

23. Archivo Histórico de la Secretaría de Salud. Fondo Instituto de Salubridad y Enfermedades Tropicales c22e2. México: Secretaría de Salud; 2019.

24. Archivo Histórico de la Secretaría de Salud. Fondo Secretaría de Salubridad y Asistencia c45e2. México: Secretaría de Salud; 2019.

25. Archivo Histórico de la Secretaría de Salud. Fondo Secretaría de Salubridad y Asistencia c1e2. México: Secretaría de Salud; 2019.

26. Archivo Histórico de la Secretaría de Salud. Fondo ISET/Dirección c26e6. México: Secretaría de Salud; 2019.

27. Archivo Histórico de la Secretaría de Salud. Fondo Secretaría de Salubridad y Asistencia. Resumen del Programa de Trabajo de la Dirección de Investigación en Salud Pública. México: Secretaría de Salud; 19.

28. Archivo Histórico de la Secretaría de Salud. Anexo del oficio Subsecretaría de Salubridad 116/032. México: Secretaría de Salud: 1978.

29. Archivo Histórico de la Secretaría de Salud. Oficio Subsecretaría de Salubridad 021/0359. México: Secretaría de Salud; 1978.

30. Lara-Aguilera R, Vallejo-Aguilar O, Gómez-Rojo E, Guzmán-Bracho C. Albendazol en el tratamiento de infecciones simultáneas de Trichuris trichiura y otros helmintos intestinales en niños. Bol Med Hosp Infant Mex. 1984;41:539-544.

31. Magos-López C, Sánchez-Villarreal F, Gutiérrez G, Tapia-Conyer R. Banco Nacional de Sueros. Salud Publica Mex. 1992;34:136-147.

32. The public health laboratories services: first report of the Expert Committee on Health Laboratory Methods. Suiza: World Health Organization; 1957

33. Ávila-Cisneros I. La especialización de los laboratorios de salud y su coordinación e integración. Salud Publica Mex. 1968;10:421-424.

34. Borunda-Falcón O. Nuevos laboratorios regionales de salud pública; su importancia en los programas de vigilancia epidemiológica. Salud Publica Mex. 1974;16:59-66.

35. Dirección de Laboratorios de Salud Pública-CESSLAB. México: Secretaría de Salud; 2013.

36. Laboratorio Estatal de Salud Pública. México: Instituto de Salud del Estado de México; 2019. 